63 巻 605 号 $(1997-1)$

\title{
超高圧噴射時のディーゼル噴霧の特性*
}

\author{
西 田 恵 哉*1, 落 合 裕 晶*2 \\ 新井 雅 隆*3, 廣安 博 之*1
}

\section{Characterization of Diesel Fuel Spray by Ultrahigh-Pressure Injection}

\author{
Keiya NISHIDA, Hiroaki OCHIAI, \\ Masataka ARAI and Hiroyuki HIROYASU
}

\begin{abstract}
Electronically controlled and hydraulically actuated fuel injection equipment was developed to investigate the characteristics of a diesel fuel spray at injection pressurs of up to $300 \mathrm{MPa}$. The injection equipment made it possible to keep the injection pressure almost constant during the injection period. The spray angle and the Sauter mean diameter decreased with an increase in the injection pressure in the range up to $250 \mathrm{MPa}$, whereas above this injection pressure the spray did not show such variation. Mach waves were observed around the spray when the initial penetrating velocity of the spray tip exceeded the sound velocity of the ambient gas. The distribution of the penetrating velocity of the fuel along the spray axis was measured from the Mach angles at the edge of the spray.
\end{abstract}

Key Words: Diesel Engine, Fuel Injection, Atomization, Diesel Spray, High-Pressure Injection, Sauter Mean Diameter, Spray Angle, Mach Wave

\section{1. ま え がき}

直接噴射式ディーゼル機関から排出される $\mathrm{NO}_{x}$ の 低減のため噴射時期を遅延させ，これに伴うパティキ ュレートの増加を燃料噴射の高圧化によって改善する 方法が検跗され，噴霧特性や燃焼過程の変化が調べら れている(1) (4).これらの研究では噴射压が $200 \mathrm{MPa}$ 程度までの範四に限られていた(3) (4). 本研究では,こ れまでに例のない噴射圧 $300 \mathrm{MPa}$ までの範囲で、噴 射期間中ほぼ一定の圧力で噴射を行うことのできる電 磁油圧制御方式の噴射装置を試作し，この装置から噴 射したディーゼル噴霧について, 到達距離, 噴霧角, ザウ夕平均粒径などの噴霧特性の測定を行った。ま た、噴霧のシュリーレン写真で観察された噴霧周囲の マッハ波を解析し、噴霧内部の燃料の到達速度を求め た.

\section{2. 実験装置および方法}

\section{$2 \cdot 1$ 高圧噴射装置 図 1 に高压噴射装置の概要}

* 原稿受付 1996 年 1 月26 月.

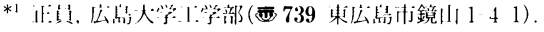

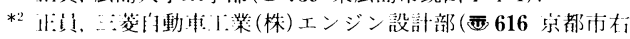
宗(大.秦貲町 1 )。

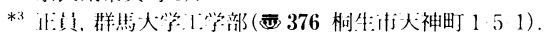

を示す. 本装置は噴射装置本体 (中央), 燃料供給・増 圧系 (右側)，針弁制御系 (左側) からなる。本体(1)には 増圧プランジャ(3)(断面積比 $12.25 ： 1$ )が内蔵され, ア

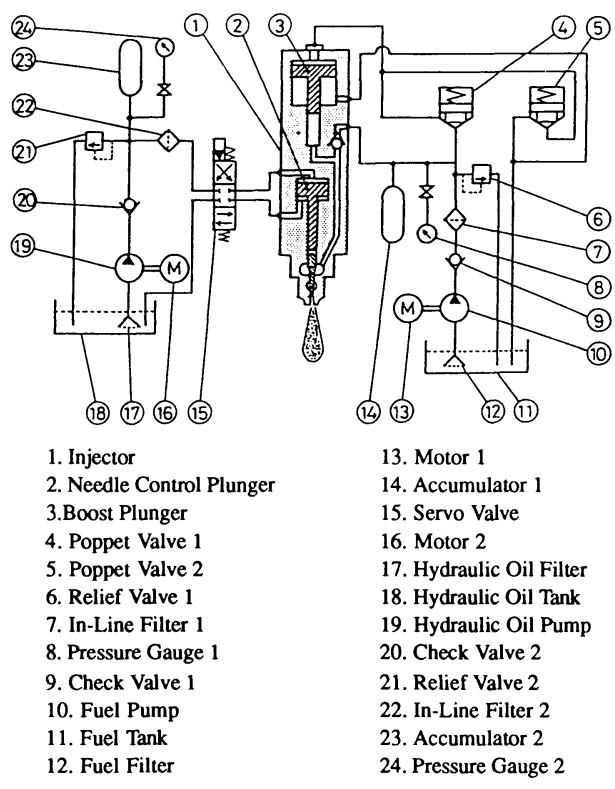

Fig. 1 Schematic diagram of an injection system 
キュムレータ(14)に蓄圧した燃料を増圧プランジャの上 部に供給することにより,アキュムレータ内の燃料压 力の 12.25 倍の圧力が増圧プランジャ下部に発生す る.

図 2 に油圧バルブの制御信号を示す。噴射の制御 は, 電磁弁付ポペット弁 1,2(図 1 中の(4), (5), 燃料の 供給および増圧プランジャの作動用) と電磁-油圧サー ボ弁 (15)，ノズル針弁の開閉用)により，次のように行 う。

（1）電磁-油圧サーボ弁(図 1 中0(15) を作動 (Pull)させて,ノズル針弁制御プランジャ(2))の上部 に油圧をかけ針弁を押し下げる。

（2）増圧ブランジャ(3) 下部に燃料を供給する.

（3）電磁弁付ポペット弁 1(4)）を開き, 2(5) を閉 じて, 増圧プランジャ上部に燃料を送る(増圧開始).

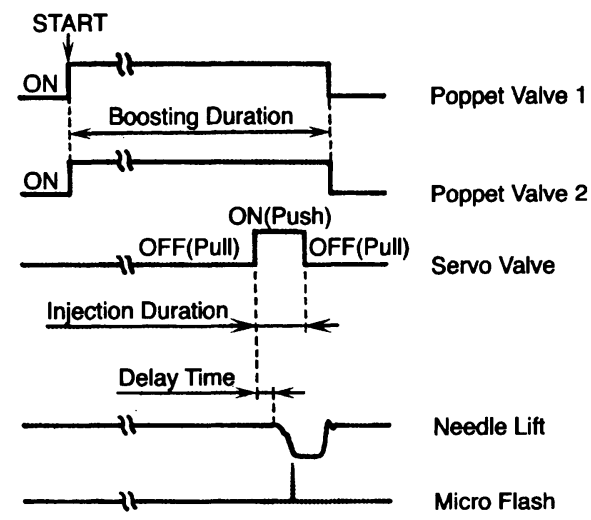

Fig. 2 Sequence diagram of signals for controlling hydraulic valves

Poppet valve 1(4) in Fig. 1)

Poppet valve 2 (5))

Servo valve (15)

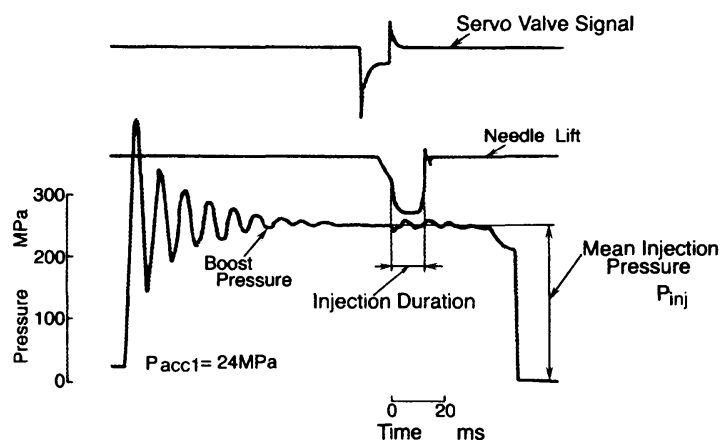

Fig. 3 Time histories of boost pressure (fuel pressure below a boost plunger [(3) in Fig. 1], servo valve signal and needle lift
（4）電磁-油圧サーボ弁(15) を作動 (Push)させて, ノズル針弁制御プランジャ(2) 上部の油圧を抜くと, ノズル針弁が上昇し始める(噴射開始).

（5）電磁-油圧サーボ弁(15) を作動(Pull)させて, ノズル針弁制御プランジャ(2))上部に油压をかけ，針 弁を押し下げる(噴射終了).

（6）電磁弁付ポペット弁 1(4)）閉じ，2(5) を開 <(増圧終了).

なお燃料および油圧回路の作動油としてディーゼル 軽油を使用した。

$2 \cdot 2$ 増圧過程と噴射過程 以上のような作動で 得られた，噴射装置本体の增圧プランジャ下部の燃料 圧力の測定結果の一例を図 3 に示す。アキュムレータ (図 1 中の(14))から増圧プランジャ下部に供給された燃 料の圧力が $P_{a c c 1}=24 \mathrm{MPa}$ の場合の結果である。電 磁弁付ポペットバルブ 2(4) を作動させると, 増圧直

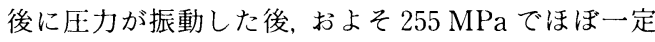
となる.さらに電磁一油圧サーボ弁(15))を作動(Pull, Push)させると，これに対応して針弁が開き，燃料が 噴射される。噴射期間中には開弁時の压力降下による わずかな圧力振動があるが, ほぼ一定の圧力で噴射し ていると見ることができる，本研究では噴射前の増圧 プランジャ下部の圧力の測定結果を噴射压 $P_{i n j}$ とし た.

図 3 の例ではアキュムレータ 1 の压力 $P_{a c c 1}$ から噴 射圧 $P_{i n j}$ への上昇比は抢よそ $10.6: 1$ で, 増圧プラン ジャの断面積比である $12.25: 1$ より小さい. 図 4 に アキュムレータ10压力と噴射压の関係を示す。アキ

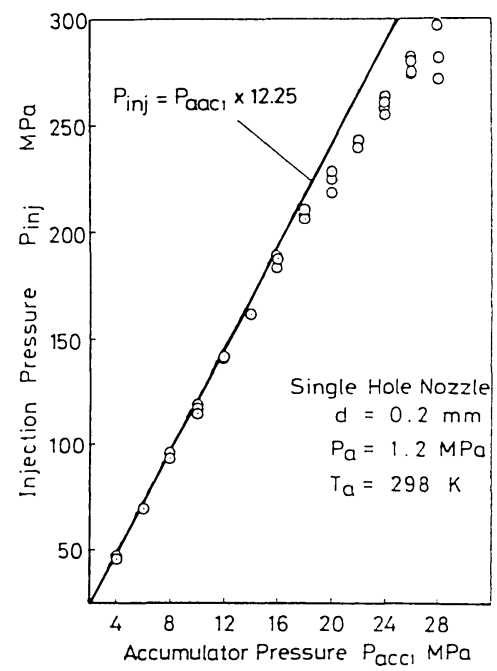

Fig. 4 Relation between fuel pressure in an accumulator (14) in Fig. 1) and injection pressure 


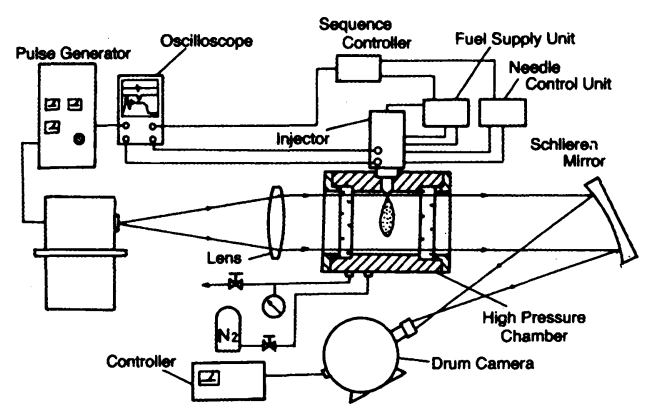

Fig. 5 Optical arrangement of focused shadow and schlieren photographies for a spray

ュムレータ1の圧力が $16 \mathrm{MPa}$ 程度までは, ほぼ 12.25 倍の噴射圧が得られているが, これを超えると 圧力の上昇比が小さくなる.これはプランジャのすき まからの漏れの影響などが大きくなるためと考えられ る.

$2 \cdot 3$ 噴霧観察用光学系高圧噴射装置から, 内 部が直径 $100 \mathrm{~mm}$, 長さ $120 \mathrm{~mm}$ の高圧容器中に噴射 された燃料噴霧を, 図 5 に示すような焦点影写真法の 光学系で撮影した. 光学系は高輝度ストロボと焦点距 離 $1 \mathrm{~m}$ の凸レンズおよび焦点距離 $2 \mathrm{~m}$ の凹面鏡から なる.ドラムカメラで撮影した噴霧の焦点影写真から 噴霧の到達距離や噴霧角などを測定した。 また画像濃 度の透過光減衰理論による解析 ${ }^{(5)}$ を行い, 噴霧のザウ 夕平均粒径を求めた。一方, シュリーレン写真法によ る噴霧周囲のマッハ波の観察の場合には, ドラムカメ ラ側の凹面鏡の焦点位置にナイフエッジを置き, 感度 を適当に調節して撮影した。

なお高圧容器中の雾囲気は, 実際の機関の燃料噴射 時期における燃焼室内雲囲気条件を想定した温度 773 $\mathrm{K}$, 压力 $3.0 \mathrm{MPa}$ の空気と密度が等しい, 室温で圧力 $1.2 \mathrm{MPa}$ の窒素とし, この中に燃料を噴射した。

\section{3. 実験結果および考察}

$3 \cdot 1$ 噴霧特性の噴射圧による変化 図 6 に噴孔 径 $d=0.2 \mathrm{~mm}$ のノズルから噴射圧 $P_{i n j}=45 \mathrm{MPa}$ か ら $280 \mathrm{MPa}$ までの範囲で噴射した噴霧の先端到達距 離を示す。いずれの噴射压の場合も, 到達距離は噴射 開始後約 $0.1 \mathrm{~ms}$ までは急激に増加し, その後はやや 緩やかに増加するようになる。 また同一時刻での到達 距離は噴射压の増加とともに大きくなる，噴射压を変 化させた場合の噴霧特性すなわち噴霧角やザウ夕平均 粒径の比較は, 噴霧先端の到達距離がほほ同一の噴霧 について行った。

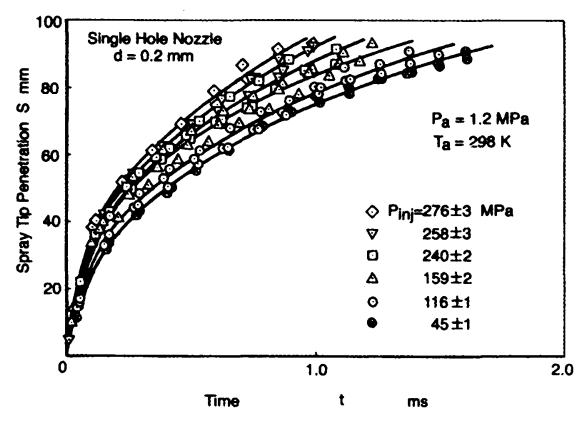

Fig. 6 Spray tip penetration

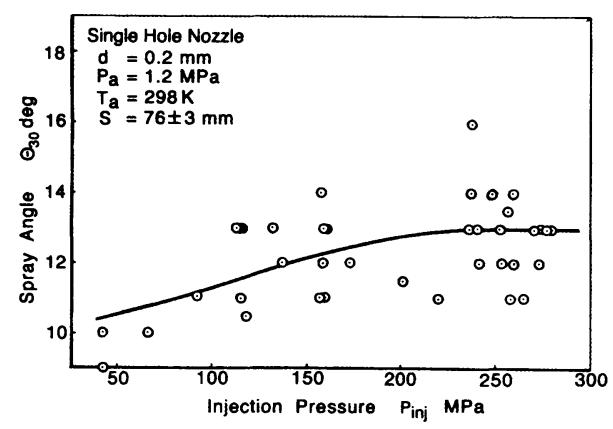

(a) $\theta_{30}$

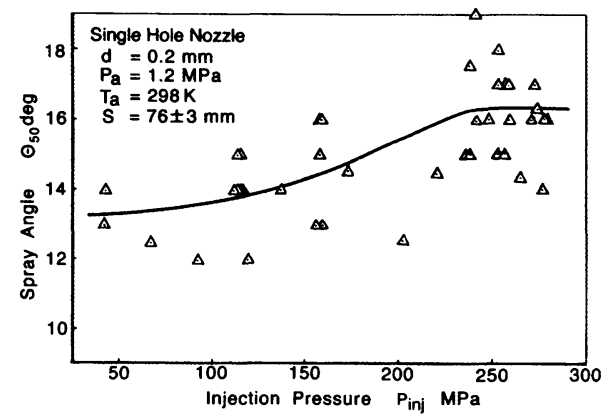

(b) $\theta_{50}$

Fig. 7 Effect of injection pressure on spray angle

噴霧角の測定結果を図 7 に示す.これは視野内で十 分発達した噴霧として噴霧先端の到達距離 $S$ が 76 $\pm 3 \mathrm{~mm}$ の噴霧を選び, 噴霧角の噴射圧力による変化 をまとめたものである. 噴霧角はその定義によって值 が異なる.ここではノズル先端からの距離が噴霧の到 達距離に対して比較的ノズルに近い $30 \mathrm{~mm}$ と, 比較 的噴霧先端に近い $50 \mathrm{~mm}$ を選び，これらの位置での 噴霧軸を中心とした噴霧外縁 2 点とノズル先端を結ぶ 直線のなす角 $\theta_{30}$ と $\theta_{50}$ とした. それぞれの結果を図 7 ( a ),（b ）に示す.いずれの定義の噴霧角でも, 噴射 圧がおよそ $250 \mathrm{MPa}$ 以下の範囲で噴霧角は噴射圧の 上昇とともに増加するが，噴射圧が $250 \mathrm{MPa}$ を超え 
ると,このような変化が頭打ちになる傾向が見られ る.

図 8 に到達距離 $S$ が 87〜93 $\mathrm{mm}$ の噴霧の先端の形 状が噴射圧の上昇とともに変化するようすを示す，先 端形状の右端の位㯰の横軸の值がその噴霧の噴射圧で ある、噴射压がおよそ $250 \mathrm{MPa}$ までの範囲で，噴射 圧の上昇とともに先端形状が偏平になり幅が大きくな る.しかし噴射圧が $250 \mathrm{MPa}$ を超えると再び先端形 状はとがり，幅も小さくなる。

図 9 に焦点影写真の画像濃度の解析から求めたザウ 夕平均粒径を示す。噴霧先端の到達距離 $S$ が $80 \pm 10$ $\mathrm{mm}$ の噴霧についての結果である。噴射圧がおよそ $250 \mathrm{MPa}$ 以下の範囲では噴射圧の上昇とともにザウ 夕平均粒径が減少するが, これ以上の噴射压ではザウ 夕平均粒径の減少が頭打ちになる傾向が見られる。

以上のような噴霧角, 噴霧先端形状, ザウ夕平均粒 径の変化は, 噴孔内部の流れの状態の変化が噴霧特性 に何らかの影響を及ぼしたものと推定されるが, はっ きりしたことは不明である。

$3 \cdot 2$ 噴霧周囲のマッハ波噴射直後の噴霧先端 到達距離が雾囲気の音速を超えると，噴霧周囲にマッ 八波が生じるのが観察された(6)(7). 図 10 に噴射圧が $P_{i n j}=275 \mathrm{MPa}$ の場合の噴霧のシュリーレン写真を示

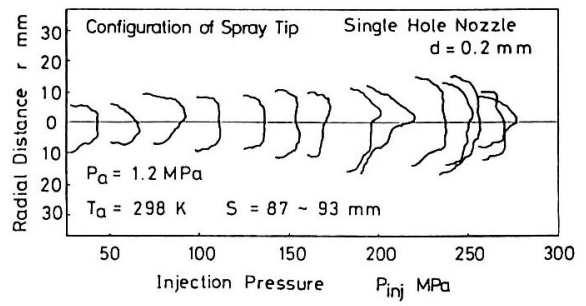

Fig. 8 Effect of injection pressure on a shape of spray tip

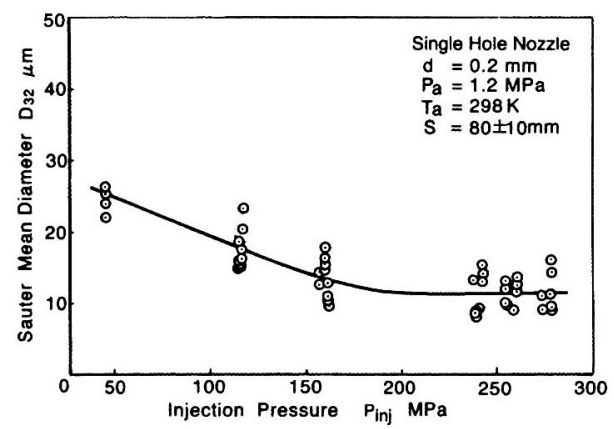

Fig. 9 Effect of injection pressure on Sauter mean diameter of a spray
す. 噴射開始後 $t=0.10 \mathrm{~ms}$ の噴霧周囲には, 先のと がった円すい状の圧縮波すなわちマッ八波が見られ る. 図 6 に示した到達距離の曲線のこう配から計算し
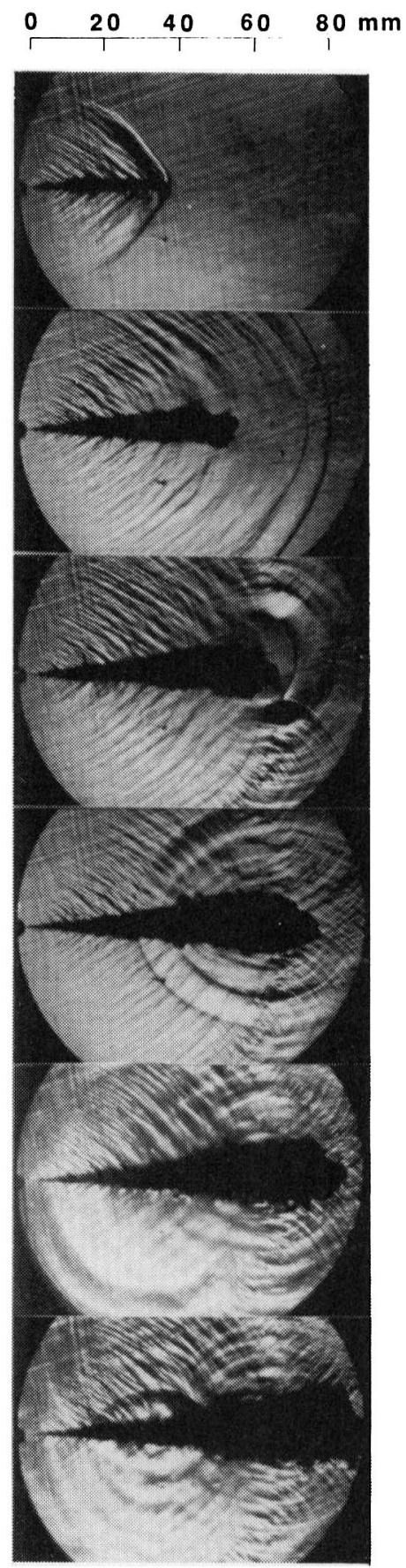

$t=0.10 \mathrm{~ms}$

0.22

0.34

0.46

0.58

0.70

Fig. 10 Schlieren photographs of a spray and Mach wave around the spray $P_{i n j}=275 \mathrm{MPa}, d=0.25 \mathrm{~mm}$, $P_{a}=1.2 \mathrm{MPa}, T_{a}=298 \mathrm{~K}$ 
た噴霧先端到達速度は, 図 11 に示すように噴射開始 後約 $0.10 \mathrm{~ms}$ 以内の間に, 雲囲気の音速である $U_{a}=$ $335 \mathrm{~m} / \mathrm{s}$ を超えていると考えられる. したがって，こ のときの先頭の圧縮波は噴霧先端に付着した状態とな っている.

噴射開始後 $0.22 \mathrm{~ms}$ になると, 噴霧先端到達速度が 減衰して䨌四気の音速より小さくなるため先頭の圧縮 波は噴霧先端から離れるが, ノズル側の噴霧周囲には マッハ波が存在している. $0.34 \sim 0.46 \mathrm{~ms}$ では先頭の 圧縮波がノズルと反対側の高圧容器壁面で反射し, 後 続の圧縮波と干渉を起こしている.

$3 \cdot 3$ 燃料の到達速度 噴射開始後 $0.46 \mathrm{~ms}$ まで の噴霧周四のマッ八波の半頂角 (マッハ角)から, 噴霧 軸方向の燃料到達速度を求めた ${ }^{(8)}$.ここで言う燃料到 達速度とはマッ八波を引き起こしている燃料塊あるい は液滴群のノズル噴孔軸方向への移動速度である。そ の結果を図 $12(\mathrm{a})$ ( d ) に示す. 図 12 中の記号で は噴霧到達方向左側のマッハ波より，○は噴霧到達方 向右側のマッハ波より求めたものである。また口は噴 霧先端の到達距離から求めた噴霧先端の到達速度であ る.なお噴射圧: $P_{i n j}=275 \mathrm{MPa}$ から噴孔部での速度 係数を 1 , ディーゼル軽油の密度を $825 \mathrm{~kg} / \mathrm{m}^{3}$ として 燃料の噴射速度を計算すると, $815 \mathrm{~m} / \mathrm{s}$ となり, 雾囲 気の音速の $U_{a}=355 \mathrm{~m} / \mathrm{s}$ を大きく超えている.

噴射開始後 $0.10 \mathrm{~ms}$ [図 12 (a)］では, 噴霧先端付 近での燃料の到達速度は雲囲気の音速である $U_{a}=$ $355 \mathrm{~m} / \mathrm{s}$ とほぼ一致している。またノズル側に近づく とともに燃料の到達速度は大きくなり, デー夕はばら ついているが，上記の燃料の噴射速度の $815 \mathrm{~m} / \mathrm{s}$ に近 づいているように見える. 噴射開始後 $0.22 \mathrm{~ms}$ 以降 [図 $12(\mathrm{~b}) \sim(\mathrm{d})$ ] になると, 噴霧先端の到達速度は 雾囲気の音速より小さくなるが，ノズルに近い側では 燃料の到達速度は䨌囲気の音速を超えている。しか し，ノズルに近い側の燃料の到達速度は時間の経過と

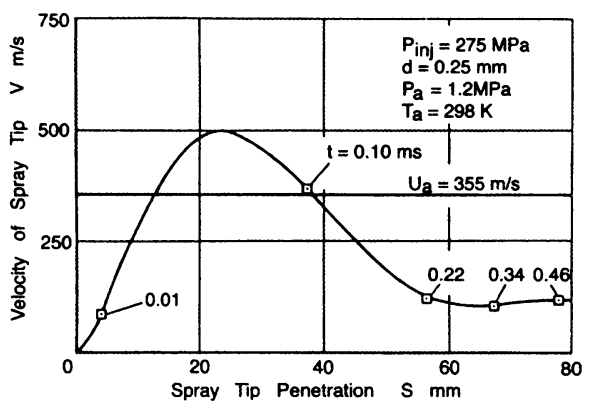

Fig. 11 Penetrating velocity of spray tip

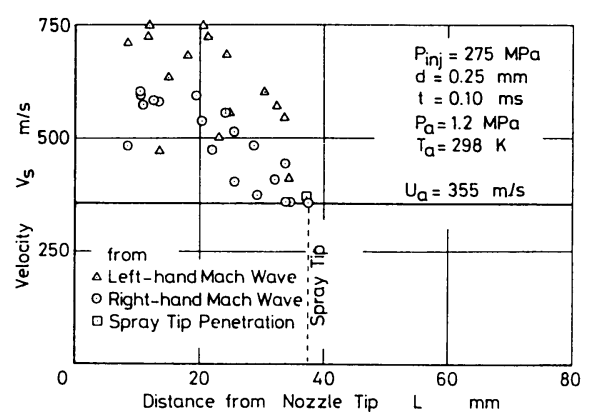

(a) $t=0.10 \mathrm{~ms}$

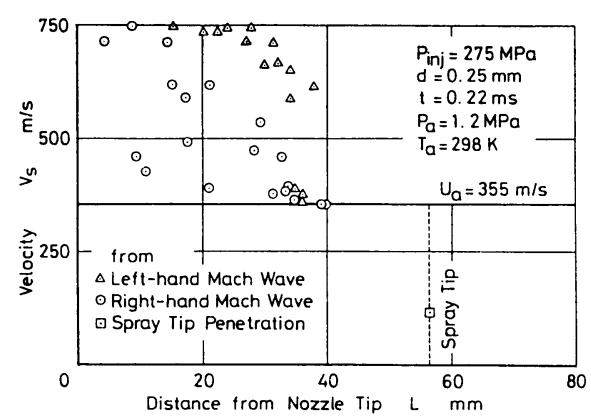

(b) $t=0.22 \mathrm{~ms}$

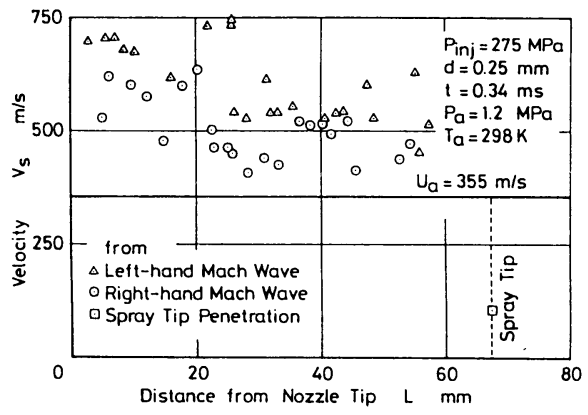

(c) $t=0.34 \mathrm{~ms}$

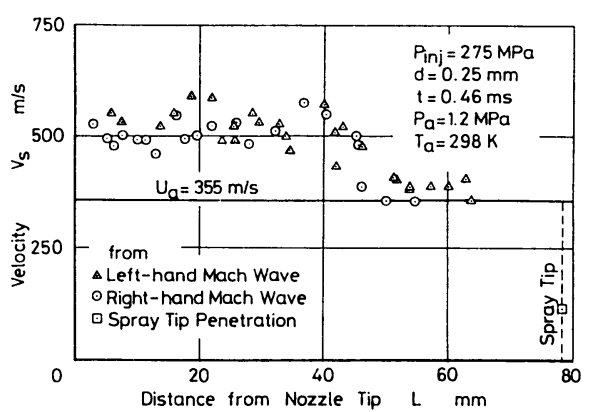

(d) $t=0.46 \mathrm{~ms}$

Fig. 12 Distribution of penetrating velocity of fuel along a spray axis 
ともに減少しており, 図 3 に示した噴射開始直後の噴 射压の低下や，噴霧内部での燃料の微粒化の進行の影 響が現れているものと思われる。

なお，図 12 を概観すると $\Delta$ のデー夕のほうが○よ り大きい傾向が見られる。これは以下のような計測法 上の理由によるものと考えられる。すなわち, 図 10 のようなナイフエッジを噴霧軸と平行に設置して撮影 したシュリーレン写真では, フィルム感度の影響もあ り, 噴霧到達方向左側と右側のマッハ波のシュリーレ ン画像(マッ八波の密度こう配に対応) の明暗の境界線 の現れ方には違いが生じる。このため, シュリーレン 画像の明暗の境界線と噴霧軸の角度として測定したマ ッ八角にも, 噴霧到達方向左側と右側で違いが現れ, $\triangle$ と○のデータに差が現れると考えられる.

\section{4. ま と め}

これまでに例のない噴射圧 $300 \mathrm{MPa}$ までの範囲で, 噴射期間中ほぼ一定の圧力で噴射を行うことのできる 電磁油圧制御方式の噴射装置を製作し,この装置から 窒温で圧力 $1.2 \mathrm{MPa}$ の窒素䨌囲気中に噴射したディ 一ゼル噴霧について, 噴霧特性の測定を行った。その 結果, 以下のことが明らかになった。

（1）噴射圧が $250 \mathrm{MPa}$ までの範囲では，噴射压 の上昇とともに噴霧角は増加しザウタ平均粒径は減少 する，しかし，これ以上の噴射圧の範囲では，このよ うな変化が頭打ちになる傾向が見られる。

（2）ノズル噴孔からの燃料の噴射速度が雾囲気の
音速を超える噴射圧では，噴霧周囲にマッハ波を生じ る. 噴霧先端の到達速度が雲囲気の音速を超えている 場合には, 先頭のマッハ波は噴霧先端に付着した状態 となる。

（3）マッ八波が見られる位置での噴霧軸方向の燃 料の到達速度は雲四気の音速を超えており，またノズ ルからの距離の増加とともにこの燃料到達速度は減少 して, 噴霧先端到達速度となる。

\section{謝辞}

噴射装置の試作にあたりヤンマーディーゼル(株)よ り多大の援助を受けた。また噴射装置の設計に関して は日本大学工学部の斎藤篤教授 [当時ヤンマーディー ゼル(株)］から貴重な助言を賜った。な打本研究の一。 部は文部省科学研究費補助金 (重点領域研究「燃焼機 構」)によることを記して謝意を表す。

\section{文献}

(1) Needham, J. R., SAE Paper, No. 891949(1989).

(2) Kato, T., ほか 4 名, SAE Paper, No. 890265(1989).

(3) Kamimoto, T., ほか 2 名, SAE Paper, No. $871610(1987)$.

（4）坂根篤・ほか 3 名，日本舶用機関学会誌，231(1988)，47 52 .

（5）神本武征. 内燃機関, 25-314(1986)，27-31.

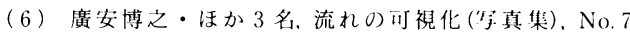
(1990), $56 \cdot 57$.

(7) Nakahira, T., ほか3 名, SAE Paper, No. 920460)(1992).

（8）藤本武助, 流体力学。(1976)，105, 養䁂堂。 